\title{
Application of Functional Equivalence Theory in Civil Engineering Text Translation
}

\author{
Junye Li, Pinglan Zhang* \\ Shaanxi University of Science and Technology, Xi'an, China \\ Email: *1412320251@qq.com
}

How to cite this paper: Li, J. Y., \& Zhang, P. L. (2019). Application of Functional Equivalence Theory in Civil Engineering Text Translation. Open Journal of Modern Linguistics, 9, 238-244. https://doi.org/10.4236/ojml.2019.94022

Received: July 15, 2019

Accepted: August 19, 2019

Published: August 22, 2019

Copyright $\odot 2019$ by author(s) and Scientific Research Publishing Inc. This work is licensed under the Creative Commons Attribution International License (CC BY 4.0).

http://creativecommons.org/licenses/by/4.0/

\begin{abstract}
Civil engineering English is more widely used and has become an indispensable part of professional fields with the rapid development of economy. Its texts and syntax features have attracted the attention of some experts. Based on the Functional Equivalence theory, this paper will provide a new method reference for relevant texts translation studies and summarize some translation strategies from words, sentences and chapters, including literal translation and sequential displacement to provide some references for professional text translation, reading and writing.
\end{abstract}

\section{Keywords}

Civil Engineering Text English, Syntactic Features, Functional Equivalence, Translation Strategy

\section{Introduction}

As Chinese architecture gradually moves towards the world, civil engineering English translation has become a crucial bridge for technical exchanges at home and abroad. For example, China's Six Major Overseas Projects, such as China-Pakistan Economic Corridor, Algeria Expressway, Baltic Pearl Project, West Texas Wind Farm, Nigeria's Zanglu Hydropower Station. These projects have deepened the friendship and economic development of various countries, and also promoted better exchange of engineering technology between the two sides. The combination of English and professional knowledge affects the translation quality of civil engineering texts. Functional translation theory has not been systematically used as the theoretical basis for civil engineering English translation. Therefore, functional translation theory will be of guiding significance to the research of civil engineering English translation, will certainly improve the 
translation quality of civil engineering English texts, broaden the thinking of civil engineering English teaching and research, and has certain reference value to the research of Chinese translation theory.

Meanwhile, Civil engineering English belongs to a branch of English for science and technology. It is highly specialized, widely read and relatively independent. In the translation of civil engineering English, the translator should accurately convey the meaning of the original text, that is, the translator should combine the characteristics of civil engineering specialty to realize the true meaning of technology and communication function.

\section{Functional Equivalence Theory}

Eugene Nida believes that "translation is to reproduce the information of the source language from meaning to style in the most appropriate, natural and equivalent language". Two forms of equivalence are reflected in its "functional equivalence" theory-formal equivalence and functional equivalence (Nida, 2004a).

Its essence is to make the source language equivalent in both meaning and form. This means that the translator should give more attention to the equivalence of form and style while expressing the source language information truly and accurately.

\section{Linguistic Features of Civil Engineering}

Civil Engineering, as a kind of Science English, is accurate in meaning, rigorous in diction, objective in expression and strict in logic. Especially, civil engineering has distinctive features in word, sentence and text, as shown in the following parts.

In scientific and technological texts, in order to ensure the professionalism, accuracy and scientific nature of the articles, a large number of professional words are widely used. The core element of English for civil engineering is precision. Therefore, the characteristic of large professional vocabulary is particularly prominent in English for civil engineering.

\subsection{The Wide Use of Highly-Technical Words}

Highly-technical Terms are involved in words and phrases with single meanings that can be simply used in one subject without any change in context or discipline. As a highly professional field, Civil Engineering generally has a set of fixed words and phrases that are exactly the core part of the learning (See Table 1, highly-technical terms).

\subsection{The Wide Use of Semi-Technical Words}

The semi-technical words are widely used in Civil Engineering English; semi-technical words will have different meanings in the different fields. Therefore, semi-technical words and phrases are usually context-dependent, textual 
Table 1. Highly-technical terms.

\begin{tabular}{cc}
\hline Highly-Technical Terms & Chinese Meaning \\
\hline Subgrade & 路基 \\
Concrete Aggregate & 混凝土集料 \\
Concrete Coarse Aggregate & 混凝土粗骨料 \\
Subgrade Filler & 路基填料 \\
\hline
\end{tabular}

cohesion and the meanings vary greatly with field. Most semi-technical words have technical-fields and ordinary English, the meanings have great differences, and some can be used in various technical fields. What's more, their meanings have no similarity (See Table 2, semi-technical words).

\subsection{The Wide Use of Non-Technical Words}

The non-technical Words are usually in the Civil Engineering English, non-technical English is seldom used in technical English, and they are usually divided into ordinary English words. Unlike technical Words, the non-technical Words are difficult and ambiguous to understand.

For example:

1) ST: After being laid, ring courses should be timely maintained to make mortars consistently moist. As the maintenance strength achieves design thickness, the support can be removed to point joints in ring courses.

TT: 拱圈砌筑后必须及时养生, 使其砂浆始终处于湿润状态, 当养生强度 达到设计厚度要求后, 可拆除支架, 再进行拱圈内勾缝工作.

Analysis: In example (1), "support" is a common English word with no specific meaning in Civil Engineering. “support” is commonly known as “支持，援 助, 支撑, 拥护”, however, according to the semantic relation of the original text, and the “support” in Chinese meaning is “支架” in Civil Engineering field.

2) ST: Foundations and pedestals are built by laying mortar rubbles. After foundation building, pedestals are built by the method of sample framework thread drawing to ensure compliable linearity and size. In addition, stones are built by bed mortar and extrusive mortar method without laying and grouting. Staggered and layered joints are proposed during laying with staggered interval not less than $10 \mathrm{~cm}$. Concave joint of $2 \mathrm{~cm}$ wide is uniformly adopted. Settlement joints are arranged according to design details.

TT: 基础, 台身采用浆砌片石砌筑. 基础砌筑完成后, 进行台身砌筑, 台身 砌筑采用样架挂线法施工, 确保线形及尺寸满足要求. 块石砌筑采用座浆和 挤浆法砌筑，严禁摆放灌浆砌筑，砌筑时应分层错缝，错开间距不应小于 10 $\mathrm{cm}$, 勾缝一律采用凹缝, 缝宽 $2 \mathrm{~cm}$, 并按设计设置沉降缝.

Analysis: In example (2), “laying” is commonly known as “放置, 产卵”, the word "laying” is “铺设” in engineering field according to the Oxford English-Chinese Dictionary. if the word "laying" is literally translated as “放置” or “产卵”, the meaning of the whole sentence is ambiguous, what's more, the word “settlement” is “沉降” in engineering field, if the word "settlement" is 
Table 2. Semi-technical words.

\begin{tabular}{clc}
\hline $\begin{array}{c}\text { Semi-Technical } \\
\text { Words }\end{array}$ & \multicolumn{1}{c}{ The Meaning of Other Field } & $\begin{array}{c}\text { The Meaning of Civil } \\
\text { Engineering }\end{array}$ \\
\hline Hanger & $\begin{array}{l}\text { “挂钩” in common words “吊杆” in } \\
\text { Transportation engineering, “悬挂器” in } \\
\text { Energy science and technology. }\end{array}$ & 吊架 \\
Stress & $\begin{array}{l}\text { “压力” in common words, “应激” in Medical } \\
\text { science and agricultural science. }\end{array}$ & 应力 \\
“网” in common words, “卷筒纸” in Printing, “网 & 腹板 \\
\hline Web & $\begin{array}{l}\text { “站, 网络” on Internet, “膜” in Biology, } \\
\text { “散热片, 薄板条” in Computer science }\end{array}$
\end{tabular}

literally translated as “解决” or “处理”, the meaning of the whole sentence is so vague that others cannot understand what it means.

Thus, these examples all embody lexical equivalence, not only in form but also in function. As can be seen from the above examples, only when words are correctly understood and sentences can be understood accurately.

\section{Features of English Sentences for Civil Engineering}

Civil engineering language is mainly scientific and technological language, which is used to describe the construction contract, process, principle and calculation formula. Therefore, civil engineering English is generally complete in meaning, tight in structure and concise in language.

\subsection{The Wide Use of Passive Sentence}

Civil engineering English generally uses a large number of passive sentences to keep the sentences structurally balanced.

For example:

1) ST: Reverse notching construction is proposed for circular culvert. In detail, as roadbed filling reaches 50 to $100 \mathrm{~cm}$ above culvert top, foundation ditch is excavated for circular culvert mounting by means of crane. Combination of labor force and machinery is suitable for foundation. After gravel cushion is paved, circular culvert foundation concretes are poured twice. Parts below culvert bottom are firstly poured with concretes. After culvert segments are laid, parts above the culvert bottom are concreted. As segment joints are assembled, upper half circle of oakum to fill seams is filled inwards from outside and the lower half circle is shimmed outwards from inside. In the total length of culvert, it is necessary to set a settlement joint every 3 to $5 \mathrm{~m}$. Upon completion of culvert mounting, it needs to carry out backfill by layers. As filling above culvert top is lower than $50 \mathrm{~cm}$, it is strictly prohibited for heavy-duty vehicles to drive through. Vibrations of road rollers on the culvert top are forbidden.

TT: 圆管涵采用反开槽施工, 路基填方填筑至管顶以上 $50 \sim 100 \mathrm{~cm}$ 时, 开 挖基槽, 进行圆管涵安装, 采用吊车安装. 基坑开挖采用人工配合机械的开 
挖方法. 铺设砂砾垫层后, 管涵基础硂分两次浇筑, 第一次浇筑管底以下部 分, 待安放管节后再浇筑管底以上部分. 管节接头拼接时, 填塞缝隙的麻絮, 上半圈应从外往里填塞, 下半圈应从里向外填塞. 涵洞全长范围内, 每 3 5 米 设置一道沉降缝. 涵管安装完毕后, 按要求分层进行回填, 管顶以上填土不 足 $50 \mathrm{~cm}$ 时, 严禁通过重型施工车辆, 压路机在管顶上部碾压时, 不允许开振 动.

Analysis: In this paragraph, there are 9 places of passive voice. The passive voice is used to indicate active meaning, "is proposed" shows the object of "circular culvert", the passive structure "is paved, are poured, are laid, are concreted, are assembled, is filled, is shimmed" mainly indicates the integrity of the sentence and avoids the top-heavy structure of the sentence and they realize the cohesion and coherence of the text. Then, the passive sentence of "are forbidden" emphasizes the meaning, $d$ which means the mandatory purpose of the passive sentence.

2) ST: Combination of excavator and self-dumping truck realizes foundation ditch excavation. The method of well point dewatering beside foundation ditch lowers groundwater level during foundation ditch excavation. In case of failure to mechanically excavate in stone foundations, small-scale explosion prevails. After the ditch is completely excavated, foundation bearing capacity is firstly tested.

$\mathrm{TT}$ : 采用挖掘机配合自卸车开挖基坑, 挖掘时在基坑旁边井点降水的方法 降低地下水位. 对于石质地基无法采用机械开挖的, 则采用小爆破开挖, 基 坑开挖完成后, 先进行地基承载力检测.

Analysis: In this example, the active voice is used in the front part of this paragraph and the passive voice is used in the back part. It is emphasized that the first step after foundation pit is completed is to carry out foundation bearing capacity test. The logical sequence of sentences is presented, which is conducive to clear and logical sentence structure. What's more, "is completely excavated, is firstly tested" reflects the consistency and the integrity of sentence structure.

\subsection{The Wide Use of Long Sentence}

A great number of long sentences are used in civil engineering translation, the following are some examples:

1) ST: Ring courses are built through wet masonry and support method during construction. It is necessary to lay symmetrically and evenly lay from arch springing at two ends to the arch top and finally lay arch top stones. During laying, radiating joints on both sides should be vertical with arch axis. Two adjacent lines of arch stones on two sides should be mutually staggered with staggered interval not less than $100 \mathrm{~mm}$. Stone specifications should comply with specification requirements. The vertical joint width ranges from 10 to $20 \mathrm{~mm}$. One or two layers can be built according to ring course thickness.

$\mathrm{TT}$ : 拱圈采用浆砌块石, 施工时采用支架法砌筑. 砌筑时采取从两端拱脚 处向拱顶方向对称，均衡地砌筑，最后砌拱顶石，砌筑时两边的辐射缝应垂 
直拱轴线, 两侧相邻两行拱石应互相错开, 错开间距应不小于 $100 \mathrm{~mm}$, 其石 料的规格要求应符合规范要求, 其纵向砌缝宽度在 10 20 mm 间. 砌筑层厚根 据拱圈厚度可砌筑一层, 也可砌筑两层.

Analysis: In this example, more prepositions and phrases are widely used, such as "through, during, is necessary to, staggered with, comply with, from... to..." In this paragraph, a large number of prepositions and phrases are used, making the sentence structure cohesive.

\section{The Translation Strategy}

Sentences can be regarded as the most basic elements when expressing complete semantics, and also the smallest translation unit existing in actual translation. Equivalence in sentence translation is embodied in three aspects: Surface Level, Rhetoric Level and Deep Level (Xu, 2009). Accordingly, the translation strategies are summarized as follows:

\subsection{Literal Translation}

According to the functional equivalence theory, if literal translation can realize the extension and connotation of the text, then domestication is not necessary (Nida, 2004b). Based on this theory, pragmatic equivalence and deep equivalence are realized at the same time as surface equivalence. For example:

1) ST: Highly weathered reef limestone macadam soil and highly weathered volcanic breccia can be used as roadbed filler, slightly weathered reef limestone is used as roadbed base stone; andesite is used as concrete coarse aggregate and asphalt surface layer macadam.

$\mathrm{TT}$ : 强风化礁灰岩碎石土及强风化火山角砾岩可以作为路基填料, 微风化 礁灰岩制作碎石作为路基基层石料, 安山岩制作碎石作为混凝土粗骨料及沥 青表处面层碎石.

1) ST: There are mainly highly weathered reef limestone, slightly weathered reef limestone, andesite and highly weathered volcanic breccia used for road construction and concrete aggregate.

TT: 用于筑路及混凝土集料的主要有强风化礁灰岩, 微风化礁灰岩, 安山 岩以及强风化火山角砾岩.

Analysis: In Example (1), Example (2), the literal translation of the sentence not only preserves the structure of the sentence, but also conveys the same information.

\subsection{Sequential Displacement}

The word order between English and Chinese is quite different, which requires the habitual expression of the receiver of the target language.

1) ST: The form of girder is variable-section pre-stressed concrete box girder. The girder height at the girder midspan is $3 \mathrm{~m}$, the girder height at the root is 5.8 $\mathrm{m}$, and the bottom plate transmits smoothly with a shape of secondary parabola.

$\mathrm{TT}$ : 主梁采用变截面预应力混凝土箱梁形式。主梁跨中梁高采用 $3 \mathrm{~m}$, 根部 
梁高采用 $5.8 \mathrm{~m}$, 底板采用二次抛物线平滑过渡.

Analysis: In this example, in English, the attributive clause is placed after the central word "The form" and needs to be translated into Chinese in advance.

\section{Conclusions}

Professional English for civil engineering has unique characteristics, and functional equivalence theory is of guiding significance. The English and Chinese languages are constantly merging, so the language features are not isolated and the translation strategies cannot be absolute. Only extensive practice can keep improving.

In this paper, Nida's functional equivalence theory and related translation strategies are used to help civil engineering English translation get a more accurate and professional understanding.

\section{Conflicts of Interest}

The authors declare no conflicts of interest regarding the publication of this paper.

\section{References}

Nida, E.A. (2004a). The Theory and Practice of Translation. Shanghai: Shanghai Foreign Language Education Press.

Nida, E.A. (2004b). Toward a Science of Translating. Shanghai: Shanghai Foreign Language Education Press.

Xu, Q.H. (2009). Research on the Application of Functional Equivalence Theory in Chinese-English Translation of Scientific English. Changchun: Jilin University. 